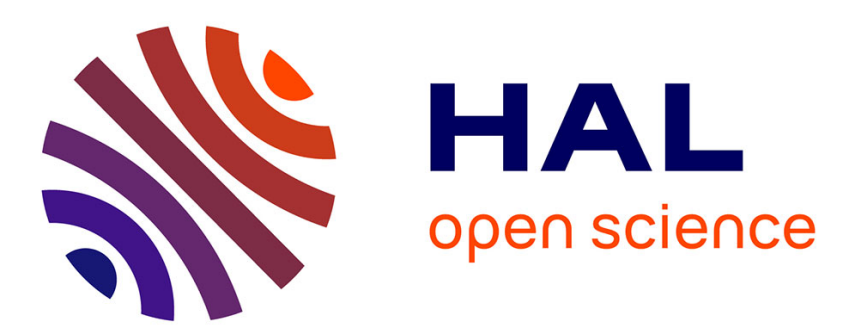

\title{
Influence of root temperature on tomato growth and nitrogen nutrition \\ Pierre Cornillon
}

\section{To cite this version:}

Pierre Cornillon. Influence of root temperature on tomato growth and nitrogen nutrition. Acta Horticulturae, 1988, 229, pp.211-218. hal-02725949

HAL Id: hal-02725949

https://hal.inrae.fr/hal-02725949

Submitted on 2 Jun 2020

HAL is a multi-disciplinary open access archive for the deposit and dissemination of scientific research documents, whether they are published or not. The documents may come from teaching and research institutions in France or abroad, or from public or private research centers.
L'archive ouverte pluridisciplinaire HAL, est destinée au dépôt et à la diffusion de documents scientifiques de niveau recherche, publiés ou non, émanant des établissements d'enseignement et de recherche français ou étrangers, des laboratoires publics ou privés. 
INFLUENCE OF ROOT TEMPERATURE ON TOMATO GROWTH AND NITROGEN NUTRITION

P. Cornillon

INRA

Domaine St-Paul

Station d'Agronomie

84140 Montfavet,

France

\section{Abstract}

Young tomato plants were grown in nutrient solution at a constant temperature : $12^{\circ} \mathrm{C}$ and $22^{\circ} \mathrm{C}$.

The tomato reacts strongly to the change in root temperature : at $12^{\circ} \mathrm{C}$, plant dry weight and water uptake are less than $70 \mathrm{p}$. cent of that observed at $22^{\circ} \mathrm{C}$.

The poor growth at $12^{\circ} \mathrm{C}$ is accompanied by a modification of plant nitrogen nutrition. At $12^{\circ} \mathrm{C}$, the organic nitrogen and nitrate accumulate in the root, while at $22^{\circ} \mathrm{C}$ they accumulate in the stem and the petiole. Concurrently the nitrate reductase activity (NAR). in the roots growing at $12^{\circ} \mathrm{C}$ is always more important than those growing at $22^{\circ} \mathrm{C}$. The NAR is more important in the blades and the difference between treatments are low. But the small growth observed at $12^{\circ} \mathrm{C}$ induces a reduction of total NAR of blades and emphazizes the further growth restriction:

1. Introduction

In the last few years, the growers have disposed of effective cultural technics to modify the root temperature in open field and under glasshouse favourising a yield increase and a much earlier yield (Brun, 1968). The increase of root temperature acts favourably on the water and nutrients absorption (Cooper, 1973). Among the nutrients the nitrate, the main substraie of the plant nitrogen nutrition, plays an important role ; the very mechanisms of this absorption by the plant are not known yet with accuracy, but it is an engergonic process (Davidian, Salsac, 1979).

The absorption and nitrate reduction are characterised as highly induced process (Skaner Boyer, 1976 ; Breteler Siegerist, 1984). The nitrate reduction would take place especially in the roots or in the leaves according to the species (Pate, 1973 ; Robin et al., 1979).

In the egg-plant and the pepper, the nitrate absorption is much less affected by a low root temperature than its migration toward the shoot (Cornillon, 1984); in the barley (Deane Drummond et al., 1980) and the tomato (Gosselin et al., 1984), the nitrate reductase activity (NRA) is higher at low temperature. But Coijc et al. (1966) infer from their observations on maize that the nitrate reductase activity would strongly decrease by cooling roots. 
In this paper, we report the experiments on the absorption, migration and the nitrate reduction by tomato.

2. Materials and methods

Plant material

Seeds of tomato cultivar M63-5 were sown on the 20th of september; the germination took place between the $28 \mathrm{th}$ and the 30th and they were planted october 9 th into plastic pot containing 1 litre of one half Hoagland solution containing: $6,5 \mathrm{meq} \mathrm{NO}_{3}^{-}, 1,0$ meq $\mathrm{SO}_{4}^{--}, 0,5$ meq $\mathrm{H}_{2} \mathrm{PO}_{4}^{-}$, 3,5 meq K$, 3,0$ meq $\mathrm{Ca}^{++} 1,0 \mathrm{meq} \mathrm{Mg}^{++}$and 0,5 meq $\mathrm{NH}_{4}^{+}$.

The choice of $12^{\circ} \mathrm{C}$ and $22^{\circ} \mathrm{C}$ root temperatures take previous observations into account and they are applied between the 19 th october and the 7 th november.

\section{Analysis}

The water consumption was read twice a week.

Plant samples were taken at four dates to measure dry matter production, nitrate and kjeldahl nitrogen accumulation.

In the same time, the nitrate reductase activity in vivo is measured with $\mathrm{NO}_{3}^{-}$addition (Robin, 1979).

3. Results

\subsection{Growth evolution}

Dry matter production at $12^{\circ} \mathrm{C}$ declined on the $3 \mathrm{~d}$ day of treatment compared at $22^{\circ} \mathrm{C}$ and the difference increases with the time (fig. 1). The $\mathrm{Q}_{10}$ value was 1,37 for the total dry matter production at these two temperatures. The shoot root ratio varies between 5.3 and 8.0 at $12^{\circ} \mathrm{C}$ and between 5.9 and 7.5 at $22^{\circ} \mathrm{C}$. The curve of water consumption shows the negative influence of the low root temperature on plant growth (fig. 2). At $12^{\circ} \mathrm{C}$, the water uptake, for the production of 1 gramme dry matter, is equal to $234 \mathrm{ml}$ whereas at $22^{\circ} \mathrm{C}$ is $271 \mathrm{ml}$.

\subsection{Nitrogen nutrition}

The organic nitrogen content in the roots decreases at $22^{\circ} \mathrm{C}$ while it remains constant at $12^{\circ} \mathrm{C}$ (fig. 3). On the other hand in the blade the organic nitrogen content remains around $6,1 \%$ for the two treatments throughout the experiment. The organic nitrogen accumulation in the plant is much higher at $22^{\circ} \mathrm{C}$ since dry matter production is higher.

The root nitrate content is more important at $12^{\circ} \mathrm{C}$ than at $22^{\circ} \mathrm{C}$ while in the blades it is the contrary (fig. 4). On the third day of the experiment the nitrate content in the blades is considerably decreased especially for the $12^{\circ} \mathrm{C}$ treatment. 
The nitrate reductase activity in leaves (after a significant decrease on the $3 \mathrm{~d}$ day) was high and the difference between treatments are little significant. In roots, the activities measured at $12^{\circ} \mathrm{C}$ are always higher than those measured at $22^{\circ} \mathrm{C}$ (fig. 5).

The correlation between NR activity and tissues nitrate content is positive : 0.61 in the roots and 0.62 in the blades. But it does not appear that the NR activity and the reduced nitrogen accumulation in the roots are correlated. The quantity of reduced nitrogen is similar at $12^{\circ} \mathrm{C}$, $73.0 \mathrm{mg}$ and at $22^{\circ} \mathrm{C}, 83.9 \mathrm{mg}$ in the roots.

When we observe the division of nitrate reductase activity between roots and leaves, we note that shoots represent $90 \mathrm{p}$. cent of the total activity for most of the experiments. Only the $12^{\circ} \mathrm{C}$ treatment gives a different repartition with about $45 \%$ and $20 \%$ of the activity in the roots on the $3 \mathrm{~d}$ and the 7 th day experiment.

\section{Discussion}

The growth change between $12^{\circ} \mathrm{C}$ and $22^{\circ} \mathrm{C}$ appears to be related to a change in the plant nitrogen nutrition.

$\mathrm{NO}_{3}^{-}$accumulates in the root, showing that no substantial change occurs in the nitrate uptake when the root temperature is low, but the flux from root to shoot is lower.

The root nitrate reductase activity increases when the temperature decreases because $\mathrm{NO}_{3}^{-}$accumulates in the root. Gosselin et al. (1984) observed quite similar results during an experiment on tomato, Vendor cultivar.

The root contribution to the total plant nitrate reductase activity may be more important than $10 \%$ we observed and that correspond to the observations of various authors on other species : maize (Wallace, 1973) cotton (Radin, 1978). Effectively in the roots this enzyme do not need light and it can react night and day, all the more as the nitrate absorption is a continuous phenomenon (Miguel, 1981).

The slightest nitrate flux to the shoot gives a lower nitrate concentration in the leaves and stem at $12^{\circ} \mathrm{C}$. This lower concentration gives a lower nitrate reductase activity in the blade by weight unit that contributes to the reduction of the synthesis in plants. Gosselin et al. (1984) did not find any influence of the root temperature on the nitrate reductase activity. of the tomato blade : this result can be explained by the sampling date since in our experiment the decrease of NRA due to the low temperature can be observed only during the first week of treatment.

This experiment shows the important role of the $\mathrm{NO}_{3}^{-}$flux from the nutritive solution to the root and then to the blade in the nitrate reductase activity of this organ and its action on growth reduction observed at $12^{\circ} \mathrm{C}$ compared to $22^{\circ} \mathrm{C}$. 
Breteler, H., Siegerist, M., 1984. Effect of ammonium on nitrate utilization by roots of dwarf bean. Plant Physjol. 75:1099-1103.

Brun, R., 1968. Utilisation des films souples plastiques dans le Sud de la France, SE 3:1-15.

Coüc, Y., Lesaint, C., Le Roux, F., 1966. Influence du refroidissement des racines sur l'absorption, le métabolisme des ions et l'équilibre anions cations chez le maîs. Ann.Physiol.Vég. 8:313-320.

Cooper, A.J., 1973. Root temperature and plant growth, CAB East Malling, Kent, 4:1-72.

Cornillon, P., 1984. Influence de la température des racines sur la croissance de jeunes plants d'aubergine (Solanum melongena $\mathrm{L}_{\text {.) }}$ et de piment (Capsicum annuum L.). Agronomie, 4:543-548.

Davidian, J.C., Salsac, L., 1979. Interaction anions-cations $\left(\mathrm{Ca}^{++}, \mathrm{K}^{+}\right.$, $\mathrm{NO}_{3}^{-}, \mathrm{Cl}^{-1}$ ) et influence sur l'induction de l'activité nitrate réductase dans les racines excisées de maīs. Physiol.veg. 17:375-385.

Deane-Drummond, C.E., Clarkson, D.T., Johnson, C.B., 1980. The effect of differential root and shoot temperature on the nitrate reductase activity, assayed in vivo and in vitro in roots of Hordeum vulgare (Barley). Planta 148:455-461.

Gosselin, A., Chalifour, F.P., Trudel, M.J., Gendron, G., 1984. Influence de la température du substrat et de la fertilisation azotée sur ia croissance, le développement, la teneur en azote et l'activité de la nitrate réductase chez la tomate. Can.J.Plant.Sci. 64:181-191.

Miguel, F., 1981. Influence de la température racinaire sur l'absorption de l'azote nitrique ou ammoniacal par le melon. DEA USTL, Montpellier, $51 \mathrm{p}$.

Pate, J.S., 1973. Uptake, assimilation and transport of nitrogen compounds by plants. Soil Biol.Biochem. 5:109-119.

Radin, J.W., 1978. A physiological basis for the division of nitrate assimilation between roots and leaves. Plant Sci.L. 13:21-25.

Robin, P., 1979. Etude de quelques conditions d'extraction de la nitrate réductase des racines et des feuilles de plantules de maîs. Physiol. veg. 17:45-54.

Robin, P., Blayac, D., Salsac, L., 1979. Infiuence de l'alimentation nitique sur la teneur en nitrate et l'activité nitrate réductase des racines et des feuilles te plantules de maĩs. Physiol.veg. 17:55-66.

Robin, P., Conejero, G., Tranchant, J.P., Passama, L., Salsac, L., 1983. Mesure de la réduction du nitrate dans les feuilles intactes. Physiol. veg. 21:123-128.

Shaner, D.L., Boyer, J.S., 1976. Nitrate reductase activity in maize (Zea Mays L) leaves. 1-Regulation by nitrate fluk.

Wallace, W., 1973. The distribution and characteristics of nitrate reductase and glutamate dehydrogenase in the maize seedling. Plant physiol. $52: 191-196$. 


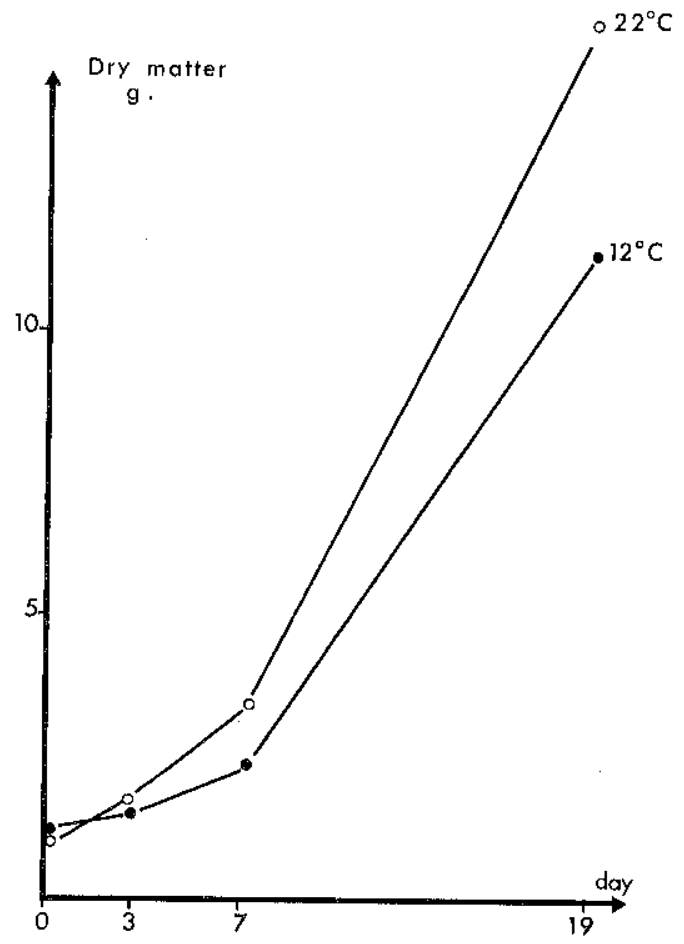

Fig. 1 - Evolution of tomato plant dry matter weight 


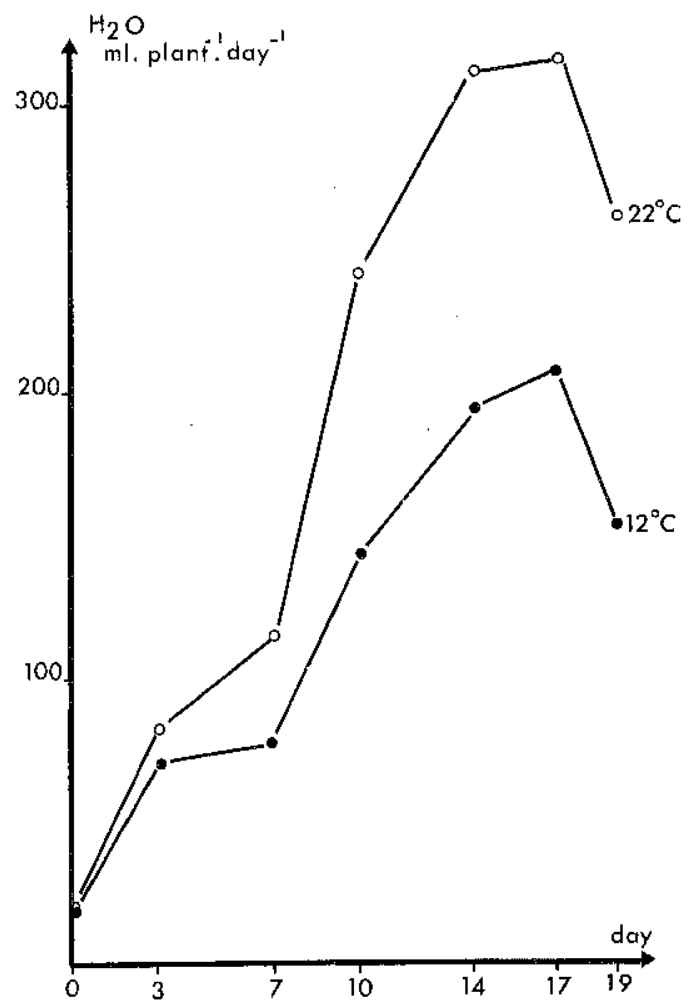

Fig. 2 - Influence of root temperature on water uptake 


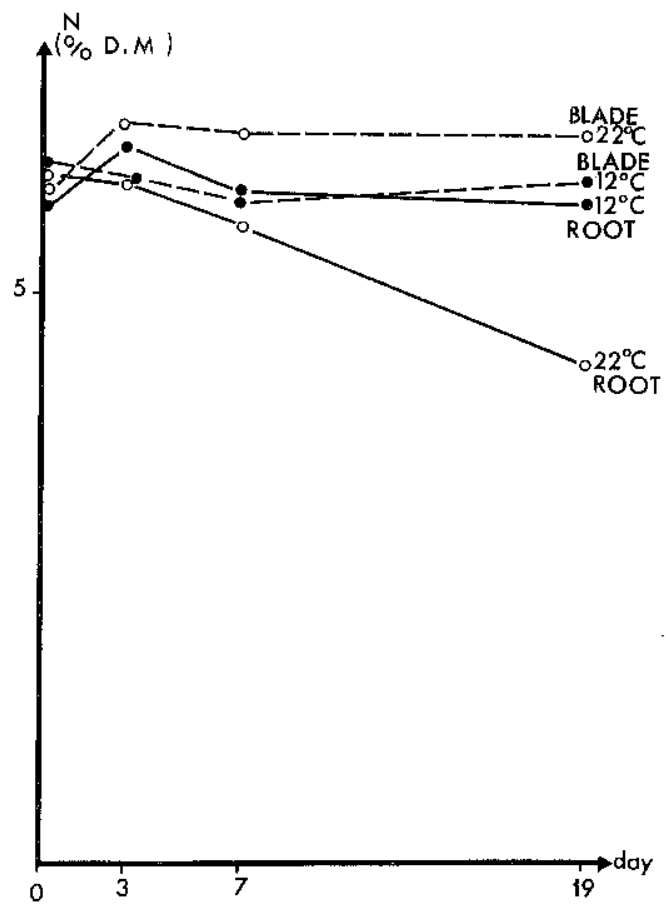

Fig. 3 - Influence of root temperature on nitrogen content of tomato root and blade

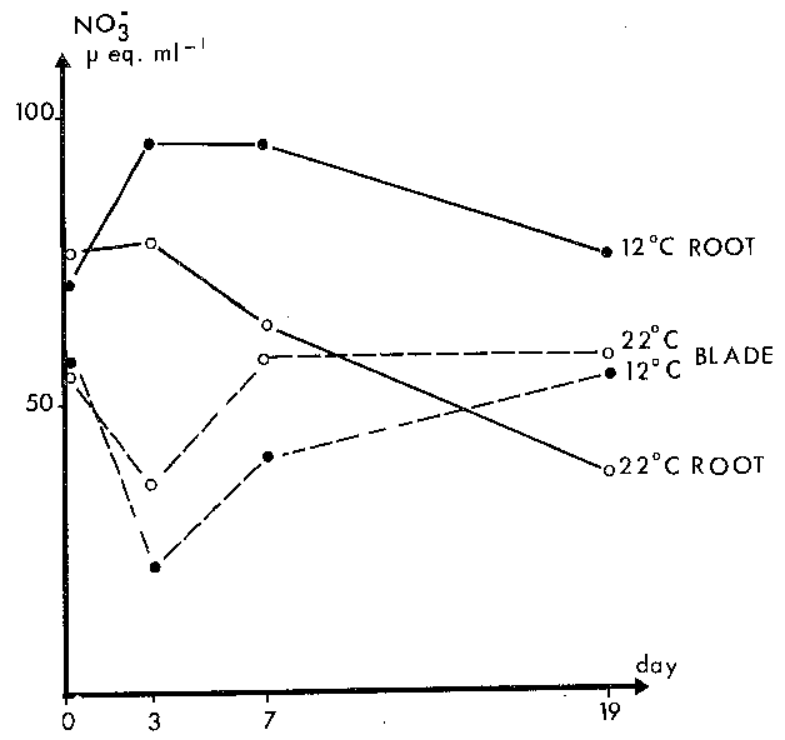

Fig. 4 - Influence of root temperature on nitrate content of tomato root and blade 


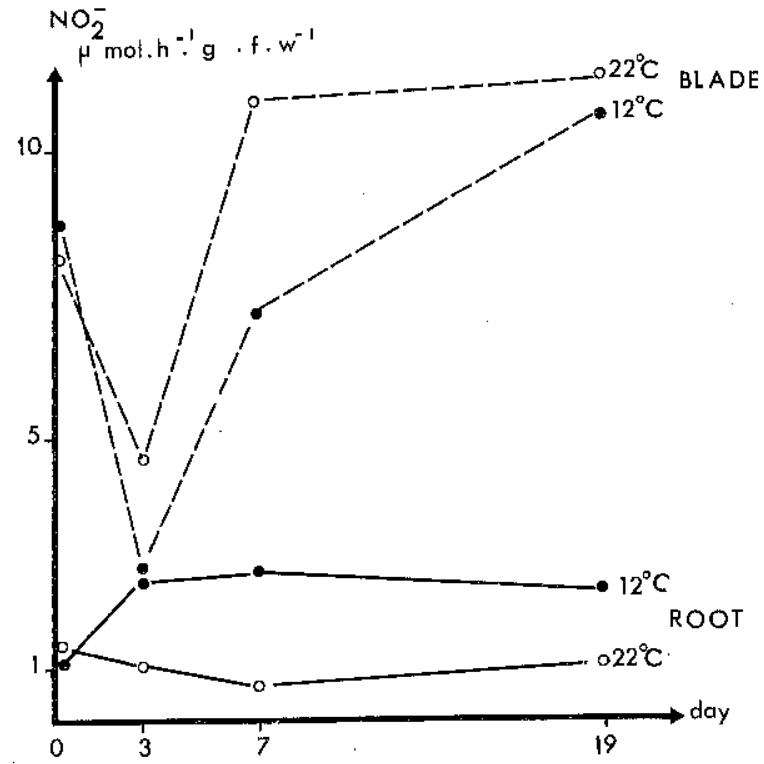

Fig. 5 - Influence of root temperature on nitrate reductase activity of tomato root and blade 